This brief investigation and publication of ovoid bottle I973.I.423 from the World Museum (National Museums Liverpool) was meant to highlight the wealth of data available for often overlooked object categories such as undecorated pottery vessels found in museum collections. Not only can a provenance and date be ascribed, but through the use of parallels, context and shape a probable function of the vessel can also be suggested. Finally, the publication of this piece can aid current excavations, where vessels of this type are continuing to emerge.

Nicky Nielsen

\title{
High and low Niles: A natural phenomenon and its mythological interpretation according to Plutarch, De Iside et Osiride 38 and Coffin Texts Spell r68*
}

Plutarch' De Iside et Osiride 38 identifies the Nile with Osiris' bodily fluids, the riparian lands with Isis, the part of the floodplain closest to the desert with Nepthys, and the desert with Seth. Moreover, the Nile flood is interpreted as Osiris impregnating Isis with Horus and Nephthys with Anubis. This can be interpreted as a new source about Seth's impotence and Osiris' committing adultery with Seth's wife Nephthys. CT spell i 68, a hitherto obscure text about 'joining the river banks,' may be rooted in the same atmosphere. The text seems to describe Isis and Nephthys as the two river banks, and may relate the low Nile to the impotence of Seth, whose testicles are said to be crushed by the hands of Shesmu.

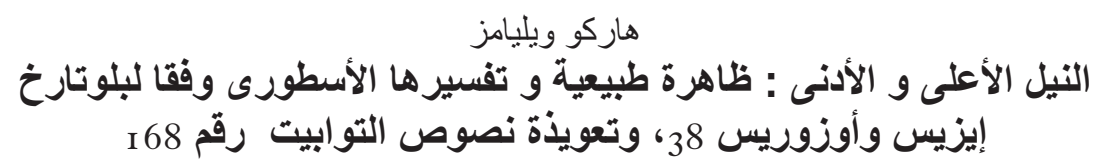

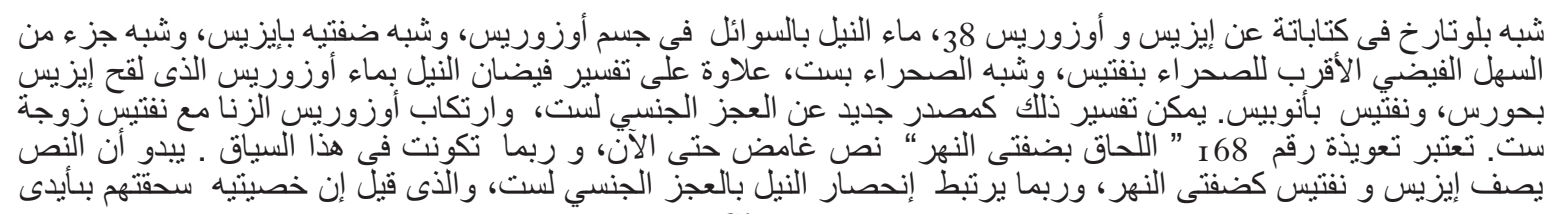
Shesmu

Some years ago, Alexandra von Lieven published a thought-provoking article under the title 'Seth ist im Recht, Osiris ist im Unrecht!'. ${ }^{\text {I }}$ As the study argues, it seems unlikely that the theology of temples dedicated to the cult of Seth would agree to the often unfavourable attitude to the 'god of confusion' ${ }^{2}$ However, since only few remains of Seth temples have survived, it is hard to find evidence for how a more positive attitude might have been articulated. In her article, von Lieven presents ancient Egyptian evidence supporting that an alternative, essentially positive, view of Seth may in fact have existed. The sources she presents suggest to her that the theology of Seth did not deny the fact that Seth killed Osiris, but that it alleged that Seth had very legitimate reasons for doing so. She argues that this violent reaction was caused by Osiris committing adultery with Seth's wife Nephthys, a sexual union that led to the birth of a son called Anubis.

I have always been convinced by von Lieven's presentation of the evidence, but, as she admits, the information remains very slender. The first aim of this article is to draw attention to a source offering striking additional information that von Lieven does not refer to. This occurs in a passage in Plutarch's De Iside et Osiride. The second aim is to discuss a far earlier text (Coffin Texts spell i68) that agrees in essential regards with Plutarch's account.

* This article was written within the framework of a Gutenberg Research Fellowship at the JohannesGutenberg-Universität Mainz. I express my gratitude to Alexandra von Lieven for reading and commenting upon a preliminary version of this article, which saved me from a serious error.

A. von Lieven, 'Seth ist im Recht, Osiris ist im Unrecht! Sethkultorte und ihre Version des OsirisMythos', ZZ̈̈S I33 (2006), I4I-50.

${ }_{2}$ The still most adequate introduction to the cult and theology of Seth is H. te Velde, Seth, God of Confusion: A Study of His Role in Egyptian Mythology and Religion (Leiden, 1967). 
Even though this text does not necessarily add to the dossier concerning Seth as a betrayed husband, Plutarch's account offers indications that may help explain one passage in the spell that has hitherto defied interpretation.

Von Lieven has cited several passages from De Iside et Osiride in support of her interpretation, but she omitted to refer to one of the clearest parts of this work, chapter 38 . This runs as follows:

Just as they view the Nile as the efflux of Osiris, thus they hold the earth to be the body of Isis, and they do not mean the whole earth, but as much as the Nile goes over, fructifying it and uniting with it; and from this union they make Horus be procreated. Horus is the maturing and mingling of the surrounding air, a process that preserves and nurtures everything; and they say that he was nurtured by Leto in the marshes around Buto. For the watery and drenched earth especially fosters the exhalations that quench and alleviate scorching heat and drought. They give the name Nephthys to the ends of the earth and the regions fringing on mountains and bordering on the sea. For this reason they also call her Teleutê (End) and say that she cohabits with Typhon. Whenever the Nile in overflowing and increasing approaches the outlying regions beyond, they call this the union of Osiris with Nephthys, which is revealed by the sprouting plants. Among these is the melilot which, according to the myth, fell down and was left behind, and so became an indication to Typhon of the wrong done to his marriage. Thus Isis bore Horus legitimately, but Nephthys bore Anubis illicitly. In the genealogies of the kings, however, they record that Nephthys, when she married Typhon, was at first barren. If they mean this in relation to the goddess rather than to the wife, they symbolize the utterly unproductive and unfruitful condition of the earth caused by her barrenness. ${ }^{3}$

The text is crystal-clear: two different zones in the Nile floodplain are identified with Isis and Nephthys respectively; both are flooded by the annual inundation, symbolized by (the efflux of) Osiris. This is interpreted as Osiris impregnating both Isis and Nephthys with his semen. The result is that Isis gives birth to Horus, and Nephthys to Anubis. The latter child is described as being illegitimate, and wrong is said to have been done to Seth's marriage. In all regards, this confirms von Lieven's account.

An interesting aspect of the passage is that it stresses the barrenness of Nephthys's marriage to Seth. This may well relate to the fact that Nephthys is said to represent marginal areas of the Nile floodplain, while her husband Seth represented the infertile desert. On the one hand, she is said to represent 'the regions fringing on mountains and bordering the sea.' The 'mountains' probably represent the desert bordering the Nile. Since the desert is the region linked to Seth, this immediately joins the floodplain areas Plutarch identifies with Nephthys. This means that 'Seth' and 'Nephthys' immediately join, just as the Nile (Osiris) and the more central parts of the floodplain (Isis). It is well known that the parts of the floodplain immediately bordering the desert are lower, and therefore wetter than those nearer to the river. These parts were accordingly less adequate for agricultural use, and this is what the 'barrenness' of Nephthys may refer to. The parts of the Delta closest to the Mediterranean are also linked to this goddess. The low elevation of these areas must have caused a steady infiltration of brackish water, also leading to a reduced fertility of the land. Thus, Nephthys impersonates those parts of the floodplain that were less fertile-a natural reality. Nevertheless, Osiris also flooded these parts, and the myth suggests that he was more successful in impregnating the goddess than the desert god Seth.

Coffin Texts spell i 68 offers an account that can be directly related to that of Plutarch, although it concerns conditions, not during the Nile flood, but during a low Nile. The extremely difficult text runs as follows: ${ }^{4}$

Translation after J. Gwyn Griffiths, Plutarch's De Iside et Osiride (s.1., I970), I 76-9.

For earlier translations, see: P. Barguet, Textes des Sarcophages égyptiens du Moyen Empire (Paris, I 986), 
CT III, 29c [168] r.w n.w hr.t-ntr

${ }^{29 \mathrm{~d}}$ dmd ihm.w.t

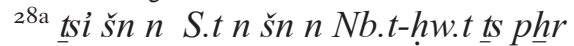

28b iwi hw33.t

${ }^{28 c}$ wšr itrw

29a 'm.n Gb mh.w

${ }^{29 \mathrm{~b}}$ dmd dr.ty $\dot{S} \sin w$ hr sm3.wy nb.ty

Leaving aside for the moment the last passage, this text can be translated as follows:

${ }^{29 c}$ The spells of the necropolis (in version $\mathrm{B}_{2} \mathrm{Bo}$ ).

${ }^{29 \mathrm{~d}}$ Joining the river banks (in version $\mathrm{M}_{5} \mathrm{C}$ ).

${ }^{28 \mathrm{a}}$ The hair of Isis is knotted to the hair of Nephthys; the hair of Nephthys is knotted to the hair of Isis.

${ }^{28 \mathrm{~b}}$ The putrefaction is running aground.

${ }^{28 c}$ The river is drying up

29a after Geb has swallowed for himself the flood.

Parts $28 \mathrm{c}$ and 29a are immediately clear: the Nile dwindles, because Geb (= the earth) swallows the water. This is an apt description of the receding water level of the Nile during the months of spring. The same must be intended by $28 \mathrm{~b}$. According to J. Rizzo, the verb $i w i$ literally means 'to run aground', 'to get stranded', and, commenting on the present passage, he argues that the 'putrefaction' refers to the natural phenomenon of vegetal remains floating in the water 'et rendues immobiles du fait de l'extrême abaissement du niveau du fleuve. ${ }^{5}$ That the humid masses of plant remains, with their undoubtedly filthy odour, ${ }^{6}$ were designated as $h w 33 . t$, 'putrefaction', does not itself call for comment. However, $h w 33 . t$ can also refer to the efflux of a dead body. ${ }^{7}$ Here, it is likely that the bodily efflux of Osiris is meant. Normally, these are called $r \underline{d} w$, and refer to the Nile flood. In the present passage, the low Nile is intended, and a different, less positive word is used.

Sentence $28 \mathrm{a}^{8}$ is less easy to interpret. All commentators agree in translating it in the way I have proposed here, ${ }^{9}$ but what does it mean? Only few scholars have endeavoured an interpretation. M. S. H. G. Heerma van Voss suggests a relationship with $C T$ IV, $238 / 9 \mathrm{~b}-\mathrm{c}$ [335]: iw tsi.n=i šn $m$ wd d3.t $r$ tr=s $n$ nšn-'I have knotted the hair to (form) an Udjat-eye during its (= the eye) day of rage.' This would refer to the hair of the sun god being knotted so as to form a uraeus on his head. ${ }^{\circ 0}$ Following this interpretation, and referring to $C T$ spell $\mathrm{r} 68$, P. Kaplony deduces from this that Isis and Nephthys are here considered as the uraei on the front of the sun god. ${ }^{\text {II }}$ However, it is hard to see what relevance this could have to the other passages translated above, all of which concern the low level of the Nile.

340; C. Carrier, Textes des sarcophages du Moyen Empire égyptien I (Le Rocher, 2004), 420-I ; R. O. Faulkner, The Ancient Egyptian Coffin Texts I (Warminster, I 973), I45; E. Meyer-Dietrich, Nechet und Nil: Ein ägyptischer Frauensarg des Mittleren Reiches aus religionsökologischer Sicht (Uppsala, 200 I), I 25; J. Rizzo, “Être sans bateau”: à propos du sens usuel du verbe $j w j$ ', $R d E 5_{5} 6$ (2005), I 71.

$5 \quad$ Rizzo, $R d E 56$, I67-75, specifically I 71.

6 Rizzo refers in this context to the interesting remarks by J. Kettel, 'Canopes, $r d w . w$ d'Osiris et OsirisCanope’, in C. Berger, G. Clerc, and N. Grimal (eds), Hommages à Yean Leclant III (BdE ro6(3); Le Caire, I 994), $325-6$.

7 L. Pantalacci, 'Wnm- $h w 33 t$ : Genèse et carrrière d'un génie funéraire’, BIFAO 83 (I983), 298-9; H. Willems, The Coffin of Heqata (Cairo $\mathcal{F} d E_{3} 6418$ ): A Case Study of Egyptian Funerary Culture of the Early Middle Kingdom (OLA 70; Leuven, I 996), 407, n. ad.

8 Of which a parallel occurs in $C T$ VI, i62a [562].

9 Apart from those cited below, see Faulkner, The Ancient Egyptian Coffin Texts I, I45; Barguet, Textes des sarcophages du Moyen Empire (Paris, I 986), 340; Carrier, Textes des sarcophages du Moyen Empire Égyptien I, 42I, Rizzo, $R d E$ 56, г7г.

ro M. S. H. G. Heerma van Voss, De oudste versie van Dodenboek I7a (Leiden, I 963), 7I.

I $\quad$ P. Kaplony, 'Bemerkungen zu fünf Texten der Ersten Zwischenzeit und der späteren i . Dynastie', MDAIK 25 ( I969), 24. 
A far more convincing interpretation was advanced by M. Münster, who links this passage to the passage of Plutarch just discussed. ${ }^{\mathrm{I} 2}$ She regards Isis and Nephthys as embodiments of the riparian lands, although unlike in that text, they would not represent the parts respectively nearest to and farthest from the river, but opposing riverbanks. By the dwindling of the river, the banks would join. The hair of the goddesses would designate the plants on both sides of the water. As the water receded, plant growth on both sides of the river would touch and be 'knotted together'. Although it is unlikely that the vegetation on either side of the river would actually join, I believe this is an adequate explanation of the poetical language of the text. Perhaps, one should in addition think of the 'stranded' vegetal remains mentioned in $28 \mathrm{~b}$, which link the two banks.

It remains to explain the last part of the text (CT III, 29b [I68]). This obscure passage has been translated by various scholars as 'The two hands of Shesmu are united over the lungs of the two ladies.' Although this rendering is grammatically possible in versions $\mathrm{S}_{\mathrm{I}} \mathrm{C}, \mathrm{S}_{2} \mathrm{C}$ and $\mathrm{B}_{2} \mathrm{~L}$, it defies interpretation. The two ladies would be likely to be Isis and Nephthys again, but what relevance could it have in this context to say that Shesmu 'united his hands' over their lungs? Moreover, in at least seven of the twelve variants, the word usually translated as 'lungs' is followed by the suffix pronoun $=f$, 'his,' which suggests that the owner of the bodily part was male. ${ }^{13}$

In fact, about half the texts do not read sm3.wy, 'lungs', but sm3.ty, 'testicles'. ${ }^{14}$ Also, the characteristics of Shesmu should be considered here. He was the god of the wine press. As such, he is linked to an instrument used to quench grapes. In a secondary interpretation, Shesmu's winepress is also regarded as a torturing instrument, used to squeeze out the heads of hostile forces, the colour of the blood issuing forth likened to red grape juice. ${ }^{15}$

I would suggest in the present text not to follow those versions that refer to sm3.wy, 'lungs', but those featuring sm3.ty, 'testicles'. This leads, for obvious reasons, to problems in those versions where the word is followed by the genitive nb.ty, 'mistresses', for what

I2 M. Münster, Untersuchungen zur Göttin Isis vom Alten bis zum Ende des Neuen Reiches (MÄS I I; Berlin, 1968), I $98-200$.

I3 I have to thank one of the reviewers of this article for this argument. The only author to pay attention to this problem is E. Meyer-Dietrich, who reads 'Auf seinen beiden Lungen, (nämlich) den beiden Damen, vereinigt Schesemu seine Hände' (Nechet und Nil, I25).

${ }_{14} C T$ III, 29b $\left[{ }_{1}^{6} 68\right] / \mathrm{B}_{2} \mathrm{Bo}, \mathrm{B}_{4} \mathrm{Bo}, \mathrm{B}_{2} \mathrm{~L}, \mathrm{~B}_{4} \mathrm{C}$; in three cases the word is no longer preserved. In the five remaining cases, no .t-ending is written. Note that this word does not occur elsewhere in the $C T$. However, it is known as a designation of the testicles of Seth ( $W b$. III, 45 I, IO), which would fit well with the interpretation to be presented below. One reviewer of this article suggested that another option should be considered: the proposal is to read sm3 as 'lock of hair' (G. van der Molen, A Hieroglyphic Dictionary of Egyptian Coffin Texts [PdÄ XV; Leiden, 2000], 492-3) because variant $\mathrm{B} 4 \mathrm{Bo}$ features the hair determinative here. This would then constitute a connection with the hair of Isis and Nephthys in 28a. The role of Shesmu would be to uphold or establish the situation described earlier in the text by holding his hands around the locks of the two goddesses. The reviewer admits that the role of Shesmu would not be clear under this interpretation, although (s)he argues based on $C T$ spell 57I that Shesmu is 'evidently generally associated with the situation of joining the riverbanks'. I do not think this is a fruitful line of argumentation. In the first place, spell $57 \mathrm{I}$ is not a spell for joining riverbanks at all. It admittedly includes the verb iab, 'to unite', in a context also mentioning riverbanks, but here it is not two riverbanks that are said to be united. Quite on the contrary, this text, which has to do with building a domain or mansion during the flood, states that 'those who are on the riverbank are united, their hearts rejoicing' (CT VI, I 70h-j [57I]). The text was thoroughly analyzed by J.-C. Moreno Garcia, who argues that spell 57I 'est sans doute le texte égyptien le plus détaillée concernant l'organisation interne d'une $h w t$ ', and from his account it becomes clear that the various parts of the domain- $h w . t$ are here associated with divine beings. Although this is an issue not specifically addressed by Moreno Garcia, Shesmu is well at his place in this account, because a wine press might suitably be part of a domain. Secondly, the hair determinative is certainly there in $\mathrm{B}_{4} \mathrm{Bo}$, but this source also features two flesh signs as a determinative, as do most of the other variants. I see no particular reason to assume that only the isolated variant $\mathrm{B}_{4} \mathrm{~B}$ o would have the correct determinative, while all others would have an incorrect one, which is moreover also implied in $\mathrm{B}_{4} \mathrm{~B}$. Finally, different from what the reviewer suggests, $\mathrm{B}_{4} \mathrm{Bo}$ does not read the masculine noun $s m$ 3, but the feminine $s m$ 3.t.

I5 S. Schott, 'Das blutrünstige Keltergerät', $Z A ̈ S 74$ ( г 938), 88-93; M. Ciccarello, 'Shesmu the Letopolite', in J. H. Johnson and E. F. Wente (eds), Studies in Honor of George R. Hughes. Fanuary I2, I977 (SAOC 39; Chicago, I 976), 43-54; Willems, The Coffin of Heqata, 437-8, with further literature. 
could the 'testicles of the two mistresses' be? However, there seems to have been some confusion among the ancient scribes about how to understand this particular part of the text. Some versions read $n b . t y$, 'the two mistresses', occasionally supplied with two goddess determinatives. However, other variants replace this by hm.ty, the nisba of $h m . t$, 'woman'. In fact, the hieratic signs for $n b$ and $h m$ can be closely similar, and $h m$ could well be the correct reading. ${ }^{16}$ This addition can be used as a qualification of feminine variants of concepts, as in s.t-hm.t, 'woman', literally 'female woman'. ${ }^{17}$ Since the word 'testicle' is also of feminine gender, the same construction might occur here. Of course, testicles are male organs par excellence, so that qualifying them as 'feminine' must have had a rather specific and probably pejorative connotation. The same holds true for the word such meaning as 'coward'. It may well be a nisba of the word hm.t, essentially meaning 'woman-like', 'effeminate'. ${ }^{18}$ As indicated by the sources referred to, this term can refer to hostile forces generally, but specifically also to Seth. Considering the relationship with the Plutarch passage pointed out by Münster, one might argue that the testicles are in fact those of Seth, who was apparently incapable of raising offspring with Nephthys. ${ }^{19}$ According to our passage, these are crushed by the hands of the torturing god Shesmu as a metaphor for the dwindling Nile. ${ }^{20}$

The suggested interpretation implies that the dwindling Nile is referred to in Osirian fashion as the 'putrefaction' being 'stranded' (28b), and in Sethian fashion as the sexual powers (the emission of semen) of Seth being negated by his testicles being crushed by Shesmu, who 'unites his hands' around them.

Accordingly, I would translate the whole spell as follows:

${ }^{28 \mathrm{~d}}$ The spells of the necropolis (in version $\mathrm{B}_{2} \mathrm{Bo}$ ).

${ }^{29 d}$ Joining the riverbanks (in version $\mathrm{M}_{5} \mathrm{C}$ ).

${ }^{28 \mathrm{a}}$ The hair of Isis is knotted to the hair of Nephthys; the hair of Nephthys is knotted to the hair of Isis.

${ }^{28 \mathrm{~b}}$ The putrefaction is running aground.

${ }^{28 \mathrm{c}}$ The river is drying up

${ }^{29 a}$ after Geb has swallowed for himself the flood,

${ }^{29 \mathrm{~b}}$ while Shemu unites his hands around the effeminate testicles. ${ }^{2 \mathrm{I}}$

There is a remaining problem: in the last sentence, 'the effeminate testicles' are understood to be those of Seth, but this god is not explicitly referred to. In many versions of the same passage, we instead read 'his effeminate testicles'. It is not made clear who the 'he' is that the text refers to. I consider this problem of secondary importance. The text as transmitted on the coffins left to us may render a version of the text that is not complete, or it may have been

I6 I have verified the signs wherever I could with photographs of the originals. $\mathrm{S}$ I C was not accessible to me, in $\mathrm{S}_{2} \mathrm{C}$ the hieroglyphic signs are near illegible, and precisely of this sign the blue paint fill has disappeared. Where the blue would have been, there are hieratic traces that resemble neither $n b$ nor $h m$. In $\mathrm{B}_{5} \mathrm{C}, n b$ is certain.

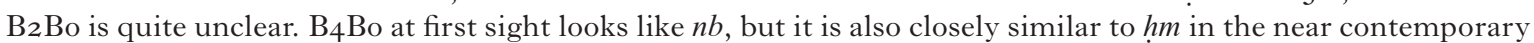
inscription Hatnub Gr. I 7, Io. $\mathrm{Nb}$ in $\mathrm{M}_{5} \mathrm{C}$ seems to be correct. All other cases read a $\mathrm{hm}$ sign.

${ }_{17} W b . \mathrm{III}, 77, \mathrm{I}-3$.

I8 Wb. III, 80,8-I I; G. E. Kadish, 'Eunuchs in Ancient Egypt', in E. B. Hauser (ed.), Studies in Honor of Fohn A. Wilson. September I2, I969 (SAOC 35; Chicago, I969), 59-60; D. Meeks, Année lexicographique I (I977) (Paris, I 980), no. 77.2682; M. Depauw, 'Notes on Transgressing Gender Boundaries in Ancient Egypt', Z̈̈̈S I30 (2003), 50-I.

r9 Compare R. Anthes, 'Egyptian Theology in the Third Millennium B.C.', FNES r8 (1959), r99: 'Furthermore, the character of Seth as the murderer of his brother appears closely correlated with the hostility of the desert and its murderous heat, and the destruction of the testicles of Seth may recall the sterility of the desert.'

20 Obviously, the various passages, of which some read nb.ty, and others hm.ty, testify to a degree of confusion on the part of ancient scribes. Ursula Verhoeven suggests as an alternative to read $n b . t y$ as a confusion of Nbw.ty, 'the One of Ombos', referring to Seth as god of Ombos.

2I Or: 'while the hands of Shesmu are united ...' 
considered self-evident, the pronoun referring to something that was generally understood. In the case of Seth, reference to whose name is often treated with circumspection, an oblique reference should not cause astonishment.

Harco Willems

\section{A hitherto unlocated Roman funerary stela from Abydos rediscovered}

Rediscovery of the stela Abdalla I08, thought lost, in the William R. and Clarice V. Spurlock Museum at the University of Illinois

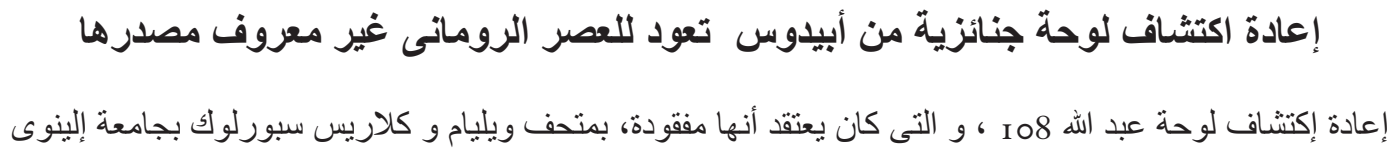

IN I 992, Aly Abdalla published a funerary stela from Abydos which was unearthed by John Garstang in 1907 , excavation no. 226GA07. ${ }^{\mathrm{I}}$ As the only evidence of the stela's existence was a negative kept in the archive of Liverpool $\mathrm{SAOS}^{2}$ it was unlocated by the time of Abdalla's research. ${ }^{3}$ With the excavators having failed to note the material as well as dimensions, the first edition of this object had to be incomplete. This rather unfortunate situation is not helped by the fact that Abdalla's publication sadly includes contradicting information. Thus, it does not become clear where exactly the stela shown on pl. 4I originated from, ${ }^{4}$ nor which one of the two catalogue nos. attributed-ro8 and 97-refer to the stela. To sum up, all that is known about this stela for certain is included in the photograph published by Abdalla.

From the published photograph, however, this round top stela appears to be of some importance, as it shows four male figures before Osiris in mummified form and wearing the white crown (left). The lower third of the stela is occupied by a blank section which might have served as a place for an inscription which was, however, never added.

The depiction of four deceased on one stela is not a common feature. From the arrangement of the group and the slightly smaller size of the figure on the right, it seems that the latter was added at a later stage, even if it exactly follows the style and shape of the figures to its left. Although this later addition makes it likely that all men depicted were part of the same family, there is no proof for Abdalla's assumption that they were brothers. ${ }^{5}$ From the documentation provided by Abdalla, no further conclusions about this stela and its possible origin can be drawn.

In 20I4, the author of this communication was able to rediscover the long lost stela Abdalla Io8 in the William R. and Clarice V. Spurlock Museum at the University of Illinois at Urbana, IL (fig. I) where its catalogue number is I 914.05.0003. ${ }^{6}$ Acquisition records kept at the Spurlock Museum indicate that this stela arrived at the University of Illinois in I9I4,

I A. Abdalla, Graeco-Roman Funerary Stelae From Upper Egypt (Oxford, i 992), pl. 4ic (catalogue no. Iо8).

Abdalla, Funerary Stelae, 49.

Abdalla, Funerary Stelae, I35.

StAbdalla 108 is said to derive from tomb 226 (find no. 226jAo7, Abdalla, Funerary Stelae, I38) and 21 8 (find no. 218gAo7, Abdalla, Funerary Stelae, 137).

Abdalla, Funerary Stelae, 49. The only known parallel from this context is the round top stLiverpool SAOS E.13 (excavation no. 226FAo7 = stAbdalla 106, Abdalla, Funerary Stelae, 48 and pl. 4ra). Here, four deceased are facing Osiris (mummified form; wearing the atef-crown) on the left while Anubis in his mummified form stands at the right. On this stela, too, a winged sun disc is shown; however, three sun rays are added and the bottom third is equally left blank. On this stela, the four deceased individuals can clearly be made out as women, probably a mother (third from the left), accompanied by her daughters, two of whom are holding plants in their right hands.

6 I am grateful to the Director of the Spurlock Museum, Wayne Pitard, for granting me the right to publish this stela and for his generosity to share with me all archival documents relating to stSpurlock I 9 I 4.5.0003. 